\title{
A DOCÊNCIA POR MEIO DA MEMÓRIA DE PROFESSORAS DO MUNICÍPIO DE ABAETETUBA/PA NO PERÍODO DE 1950 A $1970^{1}$
}

Edileuza de Sarges ALMEIDA² Secretaria Municipal de EducaçãoMoju edy_almeida@hotmail.com

Resumo: $O$ presente artigo pretende apresentar algumas considerações relacionadas ao desenvolvimento da Pesquisa de Trabalho de Conclusão de Curso-TCC intitulado de Docência Feminina: um estudo sobre a história da educação através da memória de professoras idosas, no período de 1950 a 1970, em Abaetetuba no Estado do Pará. $\mathrm{Na}$ referida pesquisa tivemos como objeto de estudo: memórias de professoras idosas do município de Abaetetuba, objetivando a análise do tipo de educação que elas receberam com o intuito de evidenciarmos a maneira como a mesma refletiu em suas práticas docentes. Metodologicamente, desenvolvemos o estudo utilizando a História Oral, na qual obtivemos relatos de experiências relevantes em suas histórias de vidas. No que concerne aos referenciais teóricos, tivemos as significativas contribuições de Portelli (2001) e Chizzotti (2003) discutindo a referida metodologia; Almeida (1998), Araújo (1993), Apple (1995) e Bezerra Neto (1995) que ressaltam a docência e educação feminina; Scott (1995) e Louro (1997) levantando a discussão sobre gênero; Foucault (1987) que aborda aspectos ligados à história, cultura e disciplinarização dos corpos e mentes femininas; Bosi (1994), Thompson (1992) e Loureiro (1999) discutindo sobre memórias, entre outros/as. Desse modo, através deste artigo pretendemos apresentar os resultados obtidos com a referida pesquisa acadêmica, ressaltando a importância de valorizar a memória e a oralidade como fontes de conhecimentos que possam contribuir para a amenização dos preconceitos ligados às professoras idosas desse município.

Palavras-chave: Docência Feminina. Gênero. Memória. Oralidade. Idosas.

\footnotetext{
${ }^{1}$ Este artigo resultou no Trabalho de Conclusão de Curso - TCC intitulado "Docência Feminina: um estudo sobre a história da educação através da memória de professoras idosas, no período de 1950 a 1970, em Abaetetuba no Estado do Pará", orientado pela Profa. M. Sc. Márcia P. Saraiva, para a obtenção de diploma do curso de Licenciatura Plena em Pedagogia, da Universidade Federal do Pará - Campus Universitário de Abaetetuba.

${ }^{2}$ Pedagoga, aluna do Curso de Especialização em Educação para as Relações ÉtnicoRaciais/IFPA e integrante do Grupo de Estudos e Pesquisa Gênero e Educação-GEPEGE do Campus de Abaetetuba.
} 
Abstract: This paper presents some considerations related to the development of the research entitled Feminine Teaching: a study over the history of education through elderly teachers' memory during 1950 and 1970 in Abaetetuba in the state of Pará. In this research we had as study object: elderly teachers' memories of Abaetetuba city, with the goal to analyze the type of education they received, to evidence the way it reflected in her practical teaching. Methodologically, we developed the study using the Oral History, in which we had reports of relevant experiences in their life histories. About the theoretic references, we had big contributions of Portelli (2001) and Chizzotti (2003) discussing the methodology used; Almeida (1998), Araújo (1993), Apple (1995) and Bezerra Neto (1995) that emphasize the teaching and feminine education; Scott (1995) and Louro (1997) arising discussion about gender; Foucault (1987) that deals aspects of story, culture and disciplining of bodies and female minds; Bosi (1994), Thompson (1992) and Loureiro (1999) discussing about memories and thereby, with this article we intend to present the results obtained with this academic research, empshasizing the importance of enhancing memory and orality as sources of knowledge that can contribute to the softening of the prejudices associated with elderly teachers of this city.

Keywords: Feminine Teaching. Gender. Memories. Orality. Elderly.

\section{Introdução}

Ao falar sobre docência feminina nas séries iniciais, geralmente pensa-se que essa é uma atividade considerada normal pela maioria dos sujeitos. Isso permite dizer que a mesma, por estar "naturalizada", apresenta uma série de aspectos ligados às questões financeiras, históricas, sociais, de gênero, entre outras que consideram a mulher como a pessoa ideal para a efetivação do processo educativo das crianças, interligando o ato de educar docente ao cuidado materno.

E com a intenção de analisar os diversos aspectos que envolvem a docência feminina, há o auxílio de temáticas que atualmente vem apresentando grande interesse pelos ambientes acadêmicos que são a Memória e Oralidade, visando o resgate de lembranças, experiências e relatos que possam contribuir com a busca de novos conhecimentos colocados à mercê da história oficial, sendo considerada como oportunidade de estudos relacionados às pessoas integrantes das classes dominadas.

Desse modo, realizei um estudo de memórias de professoras objetivando verificar como foi o processo de formação docente pelo qual estas passaram, seja nos Cursos Normais ou não, ressaltando as suas 
atuações junto aos/as discentes e oferecer a oportunidade de relatarem suas experiências e lembranças de maneira que estas professoras percebessem os seus conhecimentos relevantes para a análise, compreensão e interpretação do processo educativo do qual fizeram parte.

Nesse sentido, a oralidade permitiu a obtenção de novos conhecimentos vindos de experiências cotidianas pelas quais as docentes passaram como forma de se compreender, inicialmente, como a educação era compreendida pelas mesmas e, além disso, com o intuito de verificar quais as influências das relações de gênero nas suas "escolhas" pelo magistério. E nada mais relevante do que utilizar suas memórias como modo de valorizá-las, oferecendo-lhes a oportunidade de que sejam sujeitos de sua própria história em uma sociedade que insiste em rejeitá-las.

Segundo Bosi (1994), a memória diz respeito a uma construção histórica que evidencia experiências, fatos, conhecimentos que as pessoas apresentam e que são fundamentais para a formação dos sujeitos. Dessa maneira, o método memória e oralidade permite a possibilidade de se obter saberes significativos para o desenvolvimento de estudos, visando o oferecimento de um espaço para a exposição e valorização dos indivíduos detentores/as dessas informações.

Nesse caso, por meio desse estudo trabalhei com 04 professoras idosas que atuaram na docência durante o período de 1950 a 1970, no ensino fundamental em instituições escolares da cidade e das ilhas desse município, denominadas abaixo.

Quadro 1 - Apresentação sintética das entrevistadas.

\begin{tabular}{|l|c|c|c|c|}
\hline \multicolumn{1}{|c|}{ NOME } & IDADE & $\begin{array}{l}\text { CLASSE } \\
\text { SOCIAL }\end{array}$ & ETNIA & RELIGIÃO \\
\hline Maria Pereira da Costa & 81 anos & Baixa & Negra & Católica \\
\hline $\begin{array}{l}\text { Raimunda Nonata dos } \\
\text { S. Rodrigues }\end{array}$ & 66 anos & Baixa & Negra & Católica \\
\hline $\begin{array}{l}\text { Maria da Conceição da } \\
\text { Silva Vilhena }\end{array}$ & 61 anos & Baixa & Branca & Católica \\
\hline $\begin{array}{l}\text { Maria de Nazaré } \\
\text { Carvalho Lobato }\end{array}$ & 65 anos & Baixa & Negra & Católica \\
\hline
\end{tabular}

Fonte: Pesquisa de Campo/2007. 
Pelo exposto, o presente artigo está estruturado em 04 tópicos, nos quais abordo respectivamente:Magistério e Memória de mulheres: procedimentos metodológicos, enfatizando os referenciais metodológicos que nortearam a pesquisa; e evidenciando as discussões e resultados sobre a temática, construí os tópicos seguintes intitulados de Oralidade, Docência e gênero: elementos de análise na História da Educação, ressaltando os/as teóricos/as que tratam dos eixos mencionados buscando mostrar a relação que existe entre os/as mesmos/as nesse estudo; Infância, família e docência: memórias de professoras no qual apresento os relatos das docentes sobre esses temas e; Memórias do magistério: sonho, status, dificuldades, no qual ressalto os relatos relacionados aos valores ligados à docência e a atuação das professoras junto aos/as seus/as alunos.

Assim, a despeito da pesquisa que resultou no referido Trabalho de Conclusão de Curso não ser inédita, certamente contribui para que a educação brasileira considere as docentes idosas e os/as idosos/as em geral como sujeitos relevantes e indispensáveis para a nossa cultura, com o intuito de não apenas valorizá-los/as, mas sim, de ajudá-los/as na luta contra os preconceitos e discriminações sociais.

\section{Magistério e Memória de Mulheres: Procedimentos metodológicos}

É inegável que, para a realização de um estudo, torna-se necessário utilizar metodologias que possam auxiliar os/as pesquisadores/as durante o andamento da mesma. Desse modo, com o intuito de estudar o magistério através das memórias de professoras que o exerceram, a História Oral foi significativa na obtenção de relatos relevantes para a efetivação do estudo.

Dessa maneira, esse resgate de memórias torna-se possível quando a pesquisa utiliza a História Oral, mas especificamente a história de vida como metodologia que permite a coleta de experiências e lembranças por meio de relatos fundamentais para o estudo. Nesse sentido, a "[...] história oral é uma forma específica de discurso: história evoca uma narrativa do passado; oral indica um meio de expressão" (PORTELLI, 2001, p.10), então, utilizando-a, foi possível conseguir relatos da memória de professoras por meio de sua própria fala, ou seja, a sua própria expressão em torno do que viveram e vivem. Com isso, tive a possibilidade de 
absorver conhecimentos específicos e relevantes das lembranças, devido o referido estudo ser norteado pela oralidade e pela realidade vivida, um instrumento da história oral importante ao desenvolvimento da pesquisa.

Além disso, tomei como referência a história de vida, que possibilitou o registro de experiências pessoais, em que as professoras ficaram livres para contar suas próprias vivências. Chizzotti (2003) refere-se à história de vida como: Um instrumento de pesquisa que privilegia a coleta de informações contidas na vida pessoal de um ou vários informantes [...] as formas novas valorizam a oralidade, as vidas ocultas, o testemunho vivo de épocas ou períodos históricos (p. 95).

Isso possibilitou o estudo de pessoas singulares para a pesquisa, em que cada docente relatou o que aconteceu consigo mesma, através da oportunidade que esse estudo ofereceu a essas mulheres-professoras de se expressarem e falarem sobre suas experiências.

As observações foram direcionadas para a percepção do ambiente em que estavam acontecendo as entrevistas, pois não era fundamental só o relato, mas também o que estava sendo observado como gestos, quadros, fotos, redes, mesas, tudo que se reportassem às lembranças passadas, bem como ao presente das entrevistadas que, direta ou indiretamente, interferiam em suas falas e que foram significativos para a sua posterior análise.

No que concerne às entrevistas, elas foram do tipo semidirigida, pois houve o esclarecimento do objetivo do estudo, dispensando uma estrutura fixa e imutável no roteiro, e preferindo uma sequência lógica e flexível, possibilitando, quando necessário, acrescentar tópicos que se mostraram significativos para o estudo. Sendo assim, a partir desse momento remeto as principais discussões e resultados surgidos durante o desenvolvimento da pesquisa, enfatizando, principalmente, as informações relacionadas à docência das entrevistadas.

\section{Docência, Gênero e Oralidade: elementos de análise na História da Educação}

Compreendendo a educação de mulheres para o exercício da docência, como imbuída por questões de gênero que merecem destaque com o desenvolvimento de estudos que permitam o aprofundamento da 
temática e a possibilidade de obter conhecimentos relevantes para a análise em questão. Temos o auxílio da memória, pois é fato que a mesma é muito significativa para o resgate da valorização dos sujeitos como indivíduos essenciais para o ambiente social e, também educacional, pois por meio dela é possível que os/as mesmos/as revivam suas experiências e vivências cotidianas com o intuito de que possam perceber essas informações como fonte de conhecimento para serem realmente utilizados no cotidiano social.

Nesta perspectiva, Bosi (1994) discute que a memória é algo que a cada evocação é reconstruída, refeita e repensada, não sendo a pura evidência de como o fato aconteceu, mas é uma nova configuração das experiências vividas, por isso em cada relato alguns trechos são apresentados ou esquecidos de acordo com a seleção realizada no inconsciente dos/as indivíduos.

Essa mesma autora destaca que a memória "[...] lança uma ponte entre o mundo dos vivos e o do além, ao qual retorna tendo o que deixou à luz do sol. Realiza uma evocação: o apelo dos vivos, a vindo à luz do sol, por um momento" (BOSI, 1994, p. 89), o que possibilita aos sujeitos a ascensão de situações vividas. E ainda realiza a função de que, ao reconstruir as lembranças, o sujeito consiga aprender algo para o seu presente e compreender que o passado é relevante para a sua ampla formação (pessoal e intelectualmente). Dessa maneira, a memória assume um relevante papel no meio social, logo, sem a mesma não seria possível o acesso a conhecimentos fundamentais para o progresso social. É preciso compreender que as futuras gerações necessitam de informações e experiências passadas, para que possam perceber o real significado de culturas e de tradições ${ }^{3}$ existentes no meio social.

A memória é uma construção histórica que se modifica, não intensamente, mas constantemente de acordo com as relações, vivências e experiências do próprio indivíduo que ao buscar lembranças passadas, as revive e as reconstrói, haja vista que eles/as mesmos/as já sofreram

\footnotetext{
3 Tradição é entendida como "uma sedimentação intersubjetiva (...) quando vários indivíduos participam de uma biografia comum, cujas experiências se incorporam em um acervo comum de conhecimento" (BERGER; LUCKMANN, 1985, p.95-96), ou seja, se trata de saberes de grupos sociais que são transmitidos aos demais sujeitos através de práticas como: oralidade, documentação, entre outras.
} 
modificações físicas, psíquicas, históricas, sociais, etc., o que certamente irá influenciá-los/as em suas lembranças. Nesse sentido, por meio da memória é possível o acesso às histórias de vida, não só de pessoas consideradas importantes historicamente (autobiografias), mas também dos sujeitos "simples" que atuaram no cotidiano, nas relações do dia-adia e que foram fundamentais para o processo da construção histórica da sociedade, mesmo não estando presente na história oficial, mas que tiveram e tem participação significativa na dinâmica social.

Além disso, a memória pode oferecer aos/as ouvintes momentos de aprendizado, e também permite por meio da evocação de lembranças "[...] recordar a própria vida [...] fundamental para o nosso sentimento de identidade, continuar lidando com essa lembrança pode fortalecer, ou recapturar a autoconfiança" (THOMPSON, 1992, p. 208) em que a pessoa detentora da memória também se autoavalia, se valoriza e pode até mesmo aumentar a sua autoestima, o que é fundamental para a sua vivência no ambiente social discriminatório.

Nesse caso, a memória dos/as idosos/as é associada a um momento em que o indivíduo faz a reconstrução de suas lembranças, experiências possíveis de serem transmitidas através dos relatos. Dessa forma, a pessoa idosa assume a posição de guardiã e de transmissora de experiências passadas para que essas não se percam na história.

Em conformidade com Loureiro (1999), ser velho/a é “[...] acumular sabedoria e experiências" (p. 82), graças a sua vida longa e a possibilidade de apreensão de conhecimentos, que torna esses indivíduos mais sábios, devido as suas vivências cotidianas e ao grande capital cultural que acumularam. Isso é relevante porque geralmente os/as idosos/as são vistos/as como seres incapazes e improdutivos/as, sendo rotulados/as como sujeitos desnecessários/as, pois não apresentam força física e nem recursos financeiros que possam contribuir para o enriquecimento social, o que resulta, geralmente, em abandono e até mesmo em repúdio.

Então, tendo a memória como fonte de saberes para discutir docência feminina tem-se uma oportunidade de analisar diversas questões que implicitamente, desde a sua origem até atualmente, encontram-se no ato do magistério. Questões essas que dizem respeito a modos de se comportar, de falar, de agir e, principalmente, de atuar profissionalmente diante dos sujeitos. 
Desse modo, é preciso compreender que a educação de mulheres foi vista como um instrumento que contribuiu de maneira significativa para a formação de professoras no magistério. Educação essa baseada em valores como amor, carinho, afeto, respeito e, principalmente, obediência, transmitidos às mulheres que deveriam atender aos anseios de uma sociedade brasileira republicana e machista, contexto histórico no qual discutimos a temática.

Nesse sentido, atualmente há uma série de avanços relacionados à educação feminina. No entanto, com o decorrer dos tempos, é sabido que o momento histórico define o objetivo que a educação apresenta na formação das identidades femininas ${ }^{4}$. $\mathrm{Na}$ Idade Média, a educação das mulheres foi vista como "[...] contaminadora da consciência e perigosa para a pureza do corpo e da alma das mulheres" (ALMEIDA, 1998, p. 34), pois, de acordo com essa concepção, os conhecimentos que elas aprendessem as tornariam impuras, sujas, logo, por conta disso não poderiam aprender a ler e a escrever.

No Brasil Colônia a educação formal também foi considerada como desnecessária, pois as mulheres deveriam preocupar-se somente com o lar, com as atividades domésticas e com os maridos; sua preparação visava à apreensão de boas maneiras que fossem demonstradas futuramente ao lado de seu marido, ou seja, a "educação" era um elemento que tinha por objetivo unicamente a satisfação dos esposos com o bom comportamento da mulher (D'INCAO, 2004).

Somente com o advento da República ${ }^{5}$ no Brasil, é que a educação destinada às mulheres começa a ser repensada, isso porque os homens consideravam que estas eram as responsáveis pela formação dos/as futuros/ as cidadãos/ãs e, por isso, deveriam ser instruídas para oferecê-los/as uma

${ }^{4} \mathrm{Na}$ perspectiva de Hall (2002), a identidade é compreendida como não sendo fixa ou permanente. Desse modo, as características dos indivíduos podem mudar em conformidade com o contexto histórico, político, cultural, social, etc, em que estejam inseridos/as. Woodward (2000) ressalta ainda a intrínseca ligação entre a identidade e a diferença, havendo uma relação de dependência que determina o que os sujeitos são, ou não são, a partir das características dos outros.

${ }^{5}$ Momento histórico em que o Brasil deixa de ser governado pela Família Imperial e passa a eleger seus representantes, de forma direta ou indiretamente (Presidente e VicePresidente). 
boa educação. Essa concepção ganha ênfase principalmente com o auxílio do Positivismo ${ }^{6}$ pois o conhecimento passa a ser considerado como necessário para a educação, contribuindo para a entrada de disciplinas que oferecessem conhecimentos formais como provenientes da História e da Geografia, assim como disciplinas que ensinassem como se comportar com crianças e com a sua família, entre elas: a puericultura, psicologia, economia doméstica, entre outras.

É nesse contexto que começam a ser implantadas as Escolas Normais, buscando transmitir os conhecimentos do magistério, sendo que inicialmente tanto homens quanto mulheres eram matriculadas nesses cursos. Mas, de acordo com as mudanças sociais, econômicas e com os estereótipos ${ }^{7}$ que vão sendo construídos ao longo dos tempos, rapidamente as Escolas Normais são frequentadas por um número significativo de mulheres e, consequentemente, pela massiva evasão dos homens.

De acordo com Araújo (1993), o magistério representou uma oportunidade para a mulher adentrar no mercado de trabalho, porque os homens não se interessaram por esse ramo, pois o salário não era suficiente para o sustento da família, o que permitiu a inserção da mulher no espaço público, com remuneração, o que pode ser considerado um avanço. Esse aspecto financeiro que contribuiu para a evasão dos homens do magistério é evidenciado por Apple (1995), que ressalta ainda o advento da Industrialização em que os homens buscaram exercer outras profissões surgidas pela ampliação do mercado de trabalho. E os que ficaram nos ambientes escolares assumiram posições técnicas, administrativas e de direção, não atuando na docência, pois em outras funções recebiam salários superiores aos das professoras e não estavam envolvidos com a educação direta e o cuidado das crianças.

\footnotetext{
${ }^{6}$ Segundo Almeida (1998), essa teoria contribuiu com a ideia de que as mulheres poderiam ter acesso a conhecimentos, mas estes deviam apresentar as informações necessárias à "formação" de uma mulher que valorizasse o casamento, a família e sua pátria, não devendo cansá-las ou deixar de serem seres frágeis.

${ }^{7}$ Estereótipo é entendido como uma opinião extremamente simplificada, fixa e enviesada sobre as atitudes, comportamentos e características de um grupo cultural e social que não aquele ao qual se pertence (SILVA, 2000, p. 54).
} 
Desse modo, as modificações acerca do mercado de trabalho, principalmente a partir da segunda metade do século XIX, contribuíram para que as mulheres passassem a perceber o emprego como uma forma de socialização, ou seja, como uma oportunidade para a sua entrada nos setores públicos. Nesse contexto é que a educação feminina passa a ser realizada com o intuito de oferecer qualificação às mulheres para que pudessem exercer a função do magistério, já que esta era uma profissão emergente que necessitava de mão-de-obra feminina, pois, por meio dela, as crianças seriam educadas com amor, carinho, respeito, obediência, entre outras características femininas que o ato educativo exigia.

Dessa maneira, devido aos aspectos relacionados aos perfis masculinos e femininos, a docência nas séries iniciais passa a ser assumida pelas mulheres que por serem consideradas com uma natureza diferente da dos homens, assumem essa posição. Então, temos a ênfase das relações de gênero no magistério, entendido através de Scott (1995) como uma categoria analítica, que está além das questões biológicas, de sexo, masculino e feminino, mas que é um elemento de análise que diz respeito à construção das identidades. No entanto, no que concerne a feminilização do magistério, o aspecto biológico é valorizado de modo que o sexo feminino torna-se ideal para atuar nesse setor. Então, a mulher passa a ser formada para que, ao exercer a profissão do magistério, possa educar/cuidar do/a educando/a como um/a de seus/as filhos/as, dandolhes o cuidado, afeto, carinho que dariam a seus/as próprios/as filhos/as, isto permite dizer que o ato de ensinar no ambiente escolar é visto como um prolongamento da forma com que as crianças eram educadas em suas casas, sob os cuidados de suas mães, sendo que nas escolas esse papel é transferido às professoras.

Assim Louro afirma que:

(...) as professoras são compreendidas como mães espirituais - cada aluno ou aluna deve ser percebido como seu próprio filho ou filha. De algum modo, as marcas religiosas da profissão permanecem, mas são reinterpretadas e, sob novo discurso e novos símbolos, mantêm-se o caráter de doação e de entrega que já se associava à atividade docente (1997, p. 97). 
Dessa forma, o binômio mãe-professora ganha status social, como sendo uma pessoa qualificada para exercer o magistério e que tem uma relevância para as famílias, pois é ela que será responsável pela educação dos/as seus/as filhos/as. Além disso, essa profissão oportunizou uma qualificação (conhecimentos) a ser oferecida às mulheres que fossem exercê-la, a ser obtida nos espaços que pudessem acolhê-las e ensinarlhes os saberes considerados necessários para sua formação, os quais iriam refletir em suas práticas nos ambientes escolares junto aos/as discentes.

Nesse sentido, os sentimentos ditos femininos foram fundamentais para a relação entre a mulher e o magistério, porque através do afeto, do carinho, do amor, da generosidade, etc. ela poderia facilitar a apreensão dos conhecimentos às crianças sob seus cuidados e, com isso, obter resultados satisfatórios na educação escolar.

Além do que, ao educar a mulher para a profissão do magistério, também se educava para que tivessem um bom casamento e fossem boas mães, posições que as mesmas deveriam assumir futuramente no meio social. E, para cumprir tal objetivo social, vale ressaltar que a disciplina voltada para a educação feminina era rígida, pois se buscava moldá-las de forma intensa e significativa tanto nas Escolas Normais, quanto em suas casas; assim, na família as mulheres deveriam seguir de maneira rigorosa os ensinamentos transmitidos para que pudessem atender o ideal de mulher obediente e disciplinada que a sociedade almejava. A disciplina referida, em conformidade com Foucault (1987), se reflete na estruturação dos ambientes físicos, na vigilância severa de pais, mães e professores e, ainda, mediante o poder disciplinar, que atua de forma sutil sobre os corpos e mentes femininas, como forma de contribuir para a formação de uma mulher passiva, "adestrada", com exceção de algumas resistências ${ }^{8}$ a esse poder disciplinar.

Desse modo, quando as mães, tias, pais, entre outras pessoas transmitiam valores, conhecimentos, ideias, que deveriam ser apreendidos pelas mulheres, educavam-nas. Em geral, esses ensinamentos estavam relacionados aos valores culturais que o meio social apresentava. Isso

\footnotetext{
${ }^{8}$ Resistência para Foucault está diretamente ligada ao poder. Dessa forma, mesmo que haja estruturas, pessoas e ideais valorizados devido à hegemonia dominante, as mesmas implicam na organização de grupos opositores que evidenciam a resistência, sendo uma forma de questionamento, contradição.
} 
quer dizer que a educação feminina não acontecia somente nos ambientes escolares, mas principalmente com a influência de outras pessoas que estavam ao seu redor e que tinham a intenção em moldar uma visão de mulher passiva, submissa e "educada" socialmente.

Pelo exposto, passaremos a discutir os saberes obtidos durante as entrevistas, de maneira a estarmos enfatizando as questões ligadas à formação pessoal (infância e família) e intelectual (docência) das professoras e os principais aspectos direcionados ao exercício do magistério, ressaltando as suas contribuições com conhecimentos significativos e relevantes para a análise da história da educação nesse município.

\section{Infância, família e escolarização: memórias de professoras}

Mediante as entrevistas, percebi que desde a infância, estas professoras projetavam em suas brincadeiras, bem como nas atividades diárias, a formação de uma identidade materna e docente, como está evidenciado nos seguintes trechos.

A gente brincou sim, brincava de noite quando tinha reza naquelas casas lá, a gente ia na reza e brincava de roda né, brincava roda, aquelas músicas de rodas, pulava maré, quando vinha um, tomar banho muito, muito, muito. Meu pai não gostava muito que a gente ficasse muito na maré pulando, papai não gostava, não gostava que ele dizia que era algazarra (risos) ta fazendo algazarra ele não gostava. Aí depois eu vim pra cá, aqui também brincava, brincava, brincava roda, brincava de barrabol né, nesse tempo tinha o barrabol que é brincava na rua.(D. Diquinha, 66 anos,15/05/2007).

A gente costurava o pano, na bolinha metia um pedaço de miriti, a cabeça, a outra bolinha era o pescoço, outra era o braço, o pedaço maior era o corpo, ia prendendo, ficava tipo um boneco, desmontava, quebrava todinho né. As pernas, a gente fazia o vestido, fazia calça, tudo desse, a mão, do nosso jeito. Essa era nossa boneca. E a bola, a 
gente fazia e a gente pegava, a gente cortava seringa, a gente fazia da, da, o leite da seringueira, fazia uma bola grande de papel, por exemplo, e aí passava o, o leite de seringa na tábua assim, espalhado, e agora a gente ia passar naquela bola, aí pronto, quando terminava já tava a bola de, o brinquedo da gente (D. Conce, 61 anos, 20/04/2007).

Aí nós brincava né, brincava de roda, a gente brincava desde zinho esse negócio de escola né, uma era professora, a outra era aluna, é, muita menina era, era, só irmã nós era seis, quando os vizinhos lá perto de casa se reuniam nós brincava de casinha era, era, era (D. Maria, 81 anos, 22/04/2007).

Assim como eu brincava com um monte de boneca que eram os meus filhos eu brincava que estava dando aula, desde criança, até hoje eu me lembro. Tem vezes que eu tô me lembrando 9 (D. Nazaré, 65 anos, 01/04/2007).

Nesses relatos, verifiquei que a infância das entrevistadas foi um momento em que as mesmas deveriam aprender os fatores referentes à vida doméstica, pois, diariamente, seja através das mães ou das professoras, elas aprendiam a cuidar do lar e também a bordar, tecer crochê, etc., já que uma mulher deveria aprender as prendas domésticas, que eram fundamentais para a sua educação, o que segundo Piza (1981), é algo quase que "natural", pois elas devem conhecer e exercer estas práticas no cotidiano para tornarem-se "boas donas do lar". Desse modo, as professoras, mesmo que inconscientemente, já estavam sendo "formadas" para exercerem a função de mães e donas dos lares, por meio de valores almejados e que orientavam e regulavam a construção das identidades femininas.

\footnotetext{
${ }^{9}$ As expressões expostas nesse artigo serão apresentadas em conformidade com a maneira em que foram relatadas pelas entrevistadas.
} 
Ao adentrar aos ambientes escolares, essa preparação era mais evidente e exigia principalmente a disciplina nos ambientes escolares, pois

nós tinha que chegar sete horas na sala de aula, era, pra cantar o hino nacional, era, todo dia, na saída também, era"(D. Maria); punição "ela tinha uma palmatória quando era grave o aquele, coisas que eles se aborreciam, eles davam o bolo[...] mas era o bolo forte [...] (D. Conce) e; a premiação "era a maior alegria quando saía com o lacinho vermelho (D. Nazaré).

Este trecho permite afirmar que por meio desses aspectos relacionados a horários, punições e premiações, a disciplinarização da entrevistada era garantida, o que, conforme Foucault (1987), organizase através dos recursos utilizados para o bom adestramento, sendo significativamente evidenciado nos ambientes escolares que impregnam tais valores com o intuito de tornar os sujeitos, educacionalmente, disciplinados/as.

Durante a adolescência e juventude, há uma intensa preocupação com horário, proibições, saídas a passeios ou festas, que se justificavam pelo fato de que era preciso manter a moral das jovens intactas, sem que as mesmas realizassem alguma ação que pudesse ser motivos de boatos ou mentiras que resultassem em preconceitos e discriminações.

Ah! o papai não deixava nós sair com ninguém, não, pra nós sair era com pessoa de confiança, em festa ele não deixava nós ir, só que nós tinha um irmão mais velho. Lá ele deixava nós ir, era, mas era perto de casa. Tinha, onze horas tinha que ta em casa (D.Maria, 81 anos, 22/04/2007).

E aqui em Abaetetuba, meu amor, se uma moça chegasse a, a as vezes, nem que não tivesse acontecido, se inventassem de falar de você, nesse tempo tirava a sua dignidade, aquela menina não é mais moça, fulano fez mal para ela, pronto, você era totalmente discriminada, você não andava mais com as famílias, 
você era apontada mesmo, era totalmente afastada do convívio social, era logo, considerada uma mulher da vida, porque tinha o preconceito nesse tempo era muito forte, $[. .$.$] corresse o boato que ela$ mesmo sem ter filho, mas já, mas já não era virgem, aí era mal vista né [...] agente não podia trabalhar num ambiente aonde tivesse homem, você era logo mesmo, alijado [... [ Então, tudo isso, tudo fazia parte dessa educação da mulher, ela era, ela era preparada justamente para evitar essas situações (D. Nazaré, 65 anos, 01/04/2007).

Aqui percebo que havia uma intensa preocupação com a formação moral das mulheres. Moralidade essa que determinaria seu espaço no ambiente social. Era preciso que as mesmas seguissem o padrão de comportamento, no qual se tem estipulado às pessoas como deviam se relacionar (familiares) e os lugares que deveriam frequentar, para que não fossem estigmatizadas por estar em desconformidade com o padrão existente. Esses valores e regras são explicitados por Bezerra Neto (1995), pois segundo ele, a mulher deveria cumprir uma série de obrigações como: "[...] ser modesta em todas as suas ações; gostar de estar em casa e ajudar sua mãe [...]; detestar dissipações e profanos divertimentos" (p.08), para que fosse educada em conformidade com os padrões almejados pela sociedade e ter uma boa conduta. Conduta esta, tida como um elemento de fundamental relevância para as meninas que almejassem o exercício do magistério, temática que será abordada no próximo tópico.

\section{Memórias do magistério: sonhos, status e dificuldades}

No que concernem as lembranças relacionadas ao magistério, em tom de êxtase, as professoras relataram:

A minha maior felicidade, ser professora era uma maravilha, não pra mim foi esse o sonho, pensava desde criança em ser professora foi depois que eu vi a necessidade, a falta e, aí eu sabia né, então eu comecei a trabalhar, ajudar (D. Conce, 61 anos, 20/04/2007). 
O meu sonho era esse de dar aula, né, era, sempre foi, foi né, porque papai não era rico, ele era pobre aí nós trabalhava pra nós se manter né, ele só dava comida e nós trabalhava pra nós comprar o que nós precisava, era (D. Maria, 81 anos, 22/04/2007).

Nesses trechos, o ato de ensinar era tido como um sonho, algo prazeroso para as docentes que buscavam esse ideal desde a infância. $\mathrm{Na}$ fase adulta esse sonho é aliado às questões financeiras, quando percebiam que precisavam de algo que pudesse amenizar as necessidades financeiras, elas atuavam na sala de aula, concretizando o seu sonho e obtendo status, já que nessa época a docência era valorizada.

Dessa forma, o magistério assume relevância para a as mulheres que o percebem como a oportunidade de inserção no ambiente social e que apresenta os requisitos exigidos para atuar na referida profissão, como menciona Araújo (1993): Ser professora, na opinião de grande parte da sociedade era ter a profissão ideal da mulher, que possuía uma moral mais elevada que o homem, era mais delicada e indulgente com as crianças, além de doce, carinhosa, sentimental e paciente (p. 33).

Sendo assim, as professoras adquiriam status social obtido através do ensino e, para isso, o fato de gostar de escrever também contribuiu para o desempenho dessa função considerada intelectual. Desse modo, a formação docente era algo que oferecia certa elevação social para as mulheres professoras, que deveriam ser respeitadas, o que é reafirmado por D. Nazaré no trecho:

Criança conversa né: o que tu queres ser, e tal eu dizia: eu quero ser professora normalista, desde que eu era pequenininha, sei lá se eu achava bonito o nome né, de professora normalista. Mas nesse tempo, ser uma professora normalista era um status muito grande. Era difícil chegar a essa, a esse patamar e além de tudo, eu sempre gostei de escrever, de ler livros, de brincar (D. Nazaré, 65 anos, 01/04/2007).

Além de sonho e da necessidade financeira, torna-se importante a atuação das docentes, na qual foi notória, mediante os relatos, a relação entre alunos/as e seus/as filhos/as: "aquelas crianças no horário do meu 
trabalho eram iguais como se fossem meus filhos" (D. Conce); "olha eu tratava eles, igualmente meus filhos" (D. Maria); claramente o magistério é associado às características maternas como carinho, amor, afeto, responsabilidade e cuidados, relatados como naturais e fundamentais para as suas atuações junto aos/as alunos/as.

É significativa ainda a fala referente ao modo de ensinar no Interior desse município, pois dentre as 04 entrevistadas, 03 trabalharam inicialmente nas Ilhas dessa cidade, comentando que: "no interior é ruim porque eles querem que dê lição, tem que dá lição, ai se não der a lição(risos) (D. Diquinha)", onde tem-se explícito que os pais dos/ as alunos/as verificavam o quê e como os/as seus/as filhos/as estavam aprendendo através da lição que deveria ser feita em casa, caso contrário seria como se eles/as não tivessem feito nada no ambiente escolar, haja vista que não tinham o que exercitar nas residências.

Além disso, a prática pedagógica se caracterizava pelo uso de cartilhas do $\mathrm{ABC}$ e sabatinas, não havia separação das disciplinas e das séries, o que exigia uma avaliação de acordo com o nível de aprendizagem dos/as alunos/as. Então, de acordo com o assunto, as referidas professoras abordavam as diversas temáticas relacionadas ao tema. As salas de aula eram suas próprias casas, e por serem turmas extensas era obrigatório elaborar os deveres dos/as alunos/as na noite anterior para que, quando os/as mesmos/as chegassem à sala de aula, já estivesse preparado somente para explicar como deveriam fazer a lição, o que chamavam de "passar a escrita". Nas sabatinas, conforme os relatos nas entrevistas, os/as alunos/ as gostavam de fazê-las com o intuito de que eles/as respondessem as questões que as professoras lhes faziam. Não havia castigos para os/ as que errassem, somente os/as que acertavam eram elogiados/as e a "competição" instigava os/as alunos/as a se dedicarem, aprenderem cada vez mais. Mas em um dos relatos percebemos que a sabatina apresenta-se como instrumento negativo durante as aulas:

Olha, olha, no quadro passava no quadro pra eles, nesse tempo tinha palmatória né, tinha sabatina de tabuada, era, tinha aluno que uma vez eu dei nele, ele pulou para o terreiro me desafiou, hoje em dia Deus o livre ele por causa de mim (D. Maria, 81 anos, 22/04/2007). 
Nesse caso, o quadro era o seu único material didático e, com ele, alfabetizavam os/as discentes. No entanto, por saber que nem todos/ as os/as alunos/as a respeitavam em determinados momentos, estes eram repreendidos de maneira severa, não escondendo que os castigos aconteciam e que eram praticados de forma que conseguisse obter o controle e respeito sobre seus/as alunos/as; aqui, nesse caso, verifica-se a pedagogia tradicional eivada de autoritarismo e severidade no ambiente escolar.

No entanto, por se tratar das Ilhas, existiam dias em que não havia aulas porque a maré não permitia, ou seja, quando a água estava secando os/as alunos/as eram impedidos de ir para a escola e, nesse dia, consequentemente, não havia aula. Com o intuito de trabalhar de maneira criativa, D. Diquinha também atuava com os/as alunos/as de maneira diferente, relembrando que:

Eu me lembro bem assim fico pensando, no tempo da festa de, de assim mês de maio né, a gente fazia igual como a gente fazia no, no, na escola, como fazem as pessoas que saem com a santa é que agente sai vai nas casas e a nossa, nosso altar para Nossa Senhora, fazia as rezas todos os dias de manhã, rezava pra ela, contava, fazia coroação, fazia a, a, a oferta dos corações, oferta das flores, tempo da, de 07 de setembro também a gente fazia, eu fazia mandava fazia bandeira, bandeira brasileira pra astear, tudo cantava o hino falava, até teve um ano que até discurso teve (D. Diquinha, 66 anos, 18/06/2007).

Neste trecho há a evidencia das influências religiosas inseridas nos ambientes escolares. Além disso, a docente apresentava a preocupação em se trabalhar com as datas comemorativas e mostrar aos/as alunos/ as a importância e o significado das mesmas para a sua formação. Por isso, enfatiza-se o nacionalismo, de maneira que os instrumentos que a caracterizam como: bandeira, hino e os rituais que os envolvem são mencionados significativamente. No entanto, percebi que não havia uma análise crítica em torno dessas manifestações, somente realizava-se o que já era de costume, de praxe. 
Além dessas questões, na ausência de materiais didáticos, as entrevistadas buscavam confeccionar seus próprios instrumentos de trabalho, o que pode ser visto no seguinte trecho:

Mas eu sempre trabalhei por amor, no começo que eu, que a gente não tinha, os meus alunos não tinham também material, era muito difícil, eu não sei se era, era tipo uma, um negócio de canafista, eu cortava tudinho aquilo, tirava aquele canudinho de dentro, colocava azul, vermelha, verde, amarelo, comprava aquele papel de seda, dava a tinta, ficava de molho a tinta, aí eu mostrava a cor, aí ensinava a cor, os números e o alfabeto, porque ele é frágil, assim, a gente enrola, pra o que quer, as letras, as vogais a, e,i, o, fazia agente colocava na parede no papel, quem tinha papel nesse tempo e depois formava as consoantes, depois formava o alfabeto, depois aquelas mesmas coisas, a gente formava as sílabas e, é, era tão fácil pras crianças aprender a ler e a escrever assim (D. Conce, 61 anos, 03/04/2007).

Isto reflete as dificuldades financeiras encontradas no ambiente escolar do qual fazia parte. Com o intuito de superá-las, havia a criatividade em se imaginar materiais didáticos que pudessem ser extraídos da sua própria realidade, de sua localidade, haja vista que a vontade de ensinar e alfabetizar as crianças ultrapassava as faltas de recursos financeiros e que em conformidade com o relato, esses materiais apresentavam bons resultados, ou seja, conseguiam auxiliar no processo de aprendizagem dos/as alunos/as.

Dessa maneira, não havia questionamento da responsabilidade pública sobre a educação de qualidade, haja vista que a docente buscava superar as dificuldades apresentadas no decorrer das aulas, através de sua criatividade e seus esforços, como se o poder público não tivesse o compromisso com o ensino e com o oferecimento e a manutenção de elementos necessários para os trabalhos em sala de aula.

Além disso, havia alunas mais adiantadas que, no momento em que as professoras precisavam se ausentar para preparar a merenda, por exemplo, ou realizar outros afazeres, assumiam o cuidado da turma, o que representava uma ajuda para as docentes, haja vista que não

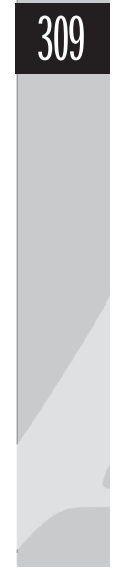


haviam outros/as profissionais para lhe auxiliar. D. Maria foi uma das entrevistadas que relatou sobre a sua atuação exaltando, os aspectos positivos, o fato de gostar de dar aula, gostar dos/as alunos/as, realizar o seu sonho; e os negativos como os castigos, sanções, intrigas que de fato ocorreram e que marcavam em suas atuações junto aos/as discentes.

A única professora entrevistada que não trabalhou nas ilhas e que também trabalhou como docente em educação física foi D. Nazaré, que buscava educar as crianças, de maneira diferente, e com a utilização de seus corpos. Após ter concluído o curso normal e também um curso de formação de professores em educação física, D. Nazaré começou a atuar nessa área que se tornou disciplina eliminatória no currículo escolar. Então, D. Nazaré denominou suas aulas como "ecléticas", haja vista que ela buscava relacioná-las com diversos assuntos e temas (esportivos, educacionais, culturais, sociais, entre outros) com o intuito de que os/as alunos/as aprendessem os conhecimentos de maneira mais relevante e significativa.

Então, trabalhavam assim no generalizado, né, utilizava muito, muito utilizava muito, então, o que eu gostava de fazer numa sala de aula, era amplo, aberto, porque a educação física não era entre quatro paredes, mas lá mesmo eu utilizava, como bem as minhas aulas de, de porque dava de primeira a quinta série, minhas aulas, de, principalmente quando eram assim para criança até terceira série, eu gostava muito de fazer um plano de aula historiada, então, eu jogava a história e desenvolvia com eles era uma mistura ali, de, de texto, de teatro, de, de e educação física, de ginástica, então, eles viviam, eu vivia com eles aquela história, aí ia relatando e fazendo todos os movimentos que aquela história ia dizendo, né, eu adorava dar aula para eles (D.Nazaré, 65 anos, 01/04/2007).

Isto ressalta que devido a sua relação com tradições e manifestações culturais, ela buscava educar de forma que pudesse integrar diversos temas e conteúdos a diferentes maneiras de ensinar, ou seja, não ensinava de acordo com conhecimentos puramente teóricos e metodologias 
técnicas, mas inovava buscando o auxílio em atividades teatrais como dramatizações, entre outras metodologias que pudessem tornar suas aulas práticas e dinâmicas e, com isso contribuir com a formação crítica e ativa dos/as seus/as discentes.

D. Nazaré didaticamente buscava trabalhar com danças, teatros, dramatizações entre outras manifestações com o intuito de que os/as alunos/as através da movimentação corporal aprendessem a se comportar e a participar ativamente no ambiente social. $\mathrm{O}$ fato de dar aula de educação física permitia o trabalho com meninos e meninas, sendo que ao tratar os times de futebol, levava os meninos para participar de jogos e torneios, estando sempre acompanhada por homens em seus trabalhos. Ressaltando que por trabalhar com meninos nunca foi desrespeitada, pois havia uma relação de respeito mútuo entre professora e alunos/as.

Pelo exposto, esses foram alguns trechos dos relatos obtidos nas entrevistas durante a pesquisa de campo. São falas consideradas normais, outras surpreendentes que dizem respeito às histórias de vidas de professoras que contribuíram de forma significativa com o processo educativo de muitas pessoas.

Histórias e experiências essas que refletem vivências baseadas em muitas proibições e imposições que foram responsáveis pelas formações de mulheres passivas e subordinadas aos seus pais e maridos. No que concerne à docência, essa foi uma atividade considerada pelas entrevistadas como prazerosa, em muitos casos até sendo a realização de seus sonhos e suas atuações estavam diretamente ligadas a aspectos como: carinho, respeito, atenção e amor, que "encaixaram-se" perfeitamente com a ideia de docência vigente na sociedade.

Assim, ressalto que essas foram algumas histórias de vida, não completas, haja vista que não seria possível, mas mostrei os principais momentos, relatos que apreendi junto a elas e posso concluir como sendo imprescindível que se valorize a memória e a oralidade como fonte de conhecimento e, principalmente, as pessoas, os sujeitos, como detentores/as de informações que muito podem auxiliar no desenvolvimento intelectual, social, cultural e, pessoal dos/as mesmos/ as, onde sua formação e o processo educativo tendem a se tornar mais relevante e significativo. 


\section{Conclusão}

Após essas discussões, propus a apresentação das principais temáticas abordadas durante a pesquisa e percebi que as docentes tiveram grande importância para a História da Educação desse município. Docência essa envolvida por vários aspectos ligados à maternidade, afeto, compromisso, entre outras que refletem a ligação entre a profissão do magistério e gênero.

Metodologicamente, no tópico inicial, apresentei a metodologia desenvolvida durante a pesquisa, a qual foi importante para a efetivação da mesma, pois possibilitou o resgate de lembranças, experiências e, principalmente, a oportunidade de escuta a sujeitos colocados a mercê da História Oficial.

Avançando na discussão evidenciei a ligação entre a oralidade, docência e gênero como elementos de análise da história da educação, em que verifiquei através dos referenciais teóricos que houve uma intensa preocupação em se moldar as mulheres para se comportarem conforme os ideais da sociedade, seja para estarem ao lado de seus futuros esposos, como para atuarem na docência junto aos seus/as alunos/as.

Desse modo, torna-se relevante mencionar que devido ao contexto histórico a educação apresentava um objetivo, mas é necessário compreender que geralmente visava à formação de uma mulher submissa que soubesse cuidar dos filhos, do marido e do lar. Então, o magistério surge como uma oportunidade de adentrar em ambientes públicos e com isso obter valores financeiros. Isso porque, as mulheres apresentavam as características necessárias para o perfil delineado para esta profissão que era: cuidar de crianças, ser carinhosa, afetuosa e, principalmente, ver os/ as alunos/as como seus/as próprios/as filhos/as.

Ideais esses encontrados nos relatos apresentados no terceiro tópico, no qual apresentei temáticas ligadas à infância, à família e à docência, percebendo que as docentes entrevistadas nas pesquisas, passaram por momentos de extrema vigilância de seus responsáveis, familiares, de maneira a não prejudicar a sua moral e poderem obter o respeito dos demais sujeitos pertencentes ao meio social em que estavam inseridas. 
No que concerne à docência feminina, no tópico final, há a evidência de que o magistério esteve ligado a três aspectos: inicialmente trata-se de um sonho, que as entrevistadas apresentavam desde as suas infâncias, em que ao brincarem projetavam suas atividades para o exercício docente, através da sua imaginação. Sonho este que estava relacionado com o status que essa profissão apresentava, haja vista que as que conseguiram exercê-la eram vistas como pessoas que obtiveram conhecimentos e formações para tal. E como também foi explicitado, essa profissão apresentava suas dificuldades que, segundo as professoras, estavam ligadas a questões de materiais didáticos, financeiros, materiais e também das próprias instalações físicas em que havia o exercício do magistério.

Dessa maneira, percebe-se que a educação de mulheres é um amplo campo de conhecimento que possibilita a análise de diversas temáticas que podem contribuir de maneira significativa com a atuação destas profissionais nos ambientes educacionais.

Por meio da oralidade e da memória de professoras do município de Abaetetuba, foi possível constatar tal afirmação, de maneira que os sujeitos da pesquisa apresentavam e valorizavam essas características tidas como fundamentais para o exercício da docência. Nesse sentido, posso dizer que por meio do resgate de lembranças, tive a oportunidade de valorizar pessoas que contribuíram de maneira significativa com a formação de outras, mas não eram valorizadas e respeitadas pelo fato de que a sociedade discrimina os/as que não fazem parte do padrão dominante como os/ idosos/as.

Assim, através desse estudo foi possível oferecer espaços para que as professoras pudessem expor suas lembranças e compreender o seu sentido e relevância, podendo oferecer uma gama de informações para os/ as profissionais que atuam com o processo educativo. Negar ou continuar reproduzindo esses conhecimentos generificados somente contribui para a manutenção de um sistema de gênero e de geração, em que somente os sujeitos que fazem parte da cultura dominante tem seus conhecimentos reconhecidos e valorizados. 
ALMEIDA, Jane Soares de. Mulher e educação: a paixão pelo possível. São Paulo: Editora UNESP, 1998.

APPLE, Michael W. Trabalho docente e textos: economia política das relações de classe e de gênero em educação In: SILVA, Tomaz Tadeu. Porto Alegre: Artes Médicas, 1995.

ARAÚJO, Rosa Maria Barboza de. A socialização da mulher no Rio Republicano. In: DINIZ, Eli (Org.). Ciências Sociais Hoje. São Paulo: HUCITEC, 1993.

BERGER, Peter L. e LUCKMANN, Thomas. A Construção Social da Realidade: tratado de Sociologia do Conhecimento. Petropólis, Vozes, 1985.

BEZERRA NETO, José Maia. O Asilo Lyndo e Protetor: práticas e representações sociais sobre a educação feminina - Belém (1870/1888). In: ALVARÉS, Maria Luzia Miranda; D'INCAO, Maria Ângela (Orgs.). A mulher existe? uma contribuição ao estudo de mulher e gênero na Amazônia. Belém: GEPEM,1995.

BOSI, Ecléa. Memória e sociedade: lembranças de velhos. São Paulo: Queiroz, 1994.

CHIZZOTTI, Antonio. Pesquisa em ciências humanas e sociais. 6a Ed. São Paulo: Cortez, 2003.

D’INCAO, Maria Ângela. Mulher e família burguesa. In: PRIORI, Mary Del. História das Mulheres no Brasil. $7^{\mathrm{a}}$. Ed. São Paulo: Contexto, 2004.

314 FOUCAULT, Michael. Vigiar e punir: nascimento da prisão. Petrópolis: Vozes, 1987.

HALL, Stuart. Identidade cultural na pós-modernidade. Rio de Janeiro: DP\&A. 2002.

LOUREIRO,Altair MacedoLahud. Velhice: encantos desencantos... reencontros. Revista Humanidades: terceira idade, v. 46, out., 1999. pp. 77-87. 
LOURO, Guacira Lopes. Gênero, sexualidade e educação: uma perspectiva pós-estruturalista. Petrópolis: Vozes, 1997.

PIZA, Edith. As professoras: o fazer-se de um ofício contaminação de práticas no trabalho de magistério: notas para reflexão. Projeto História: Revista do Programa de Estudos Pós-Graduandos em História e do Departamento de História da PUC/SP, n. 11, nov, 1981. pp.79-89.

SCOTT, Joan. Gênero: uma categoria útil de análise histórica. Educação e Realidade. v. 1, n. 1, 1995. pp. 71-100.

SILVA, Tomaz Tadeu. Teoria Cultural e Educação: um vocabulário crítico. Belo Horizonte: Autêntica, 2000.

THOMPSON, Paul. A voz do passado: história oral. Rio de Janeiro: Paz e Terra, 1992.

WOODWARD, Kathryn. Identidade e diferença: uma introdução teórica e conceitual. In: SILVA, Tomaz Tadeu da (Org.). Identidade e diferença: a perspectiva dos estudos culturais. Petrópolis: Vozes, 2000, pp. 7-72. 